\title{
Special issue on "The role of networks in entrepreneurial performance: new answers to old questions?"
}

\section{Wilson Ng \& Alison Rieple}

\section{International Entrepreneurship and} Management Journal

\section{ISSN 1554-7191}

Int Entrep Manag J

DOI 10.1007/s11365-014-0308-5

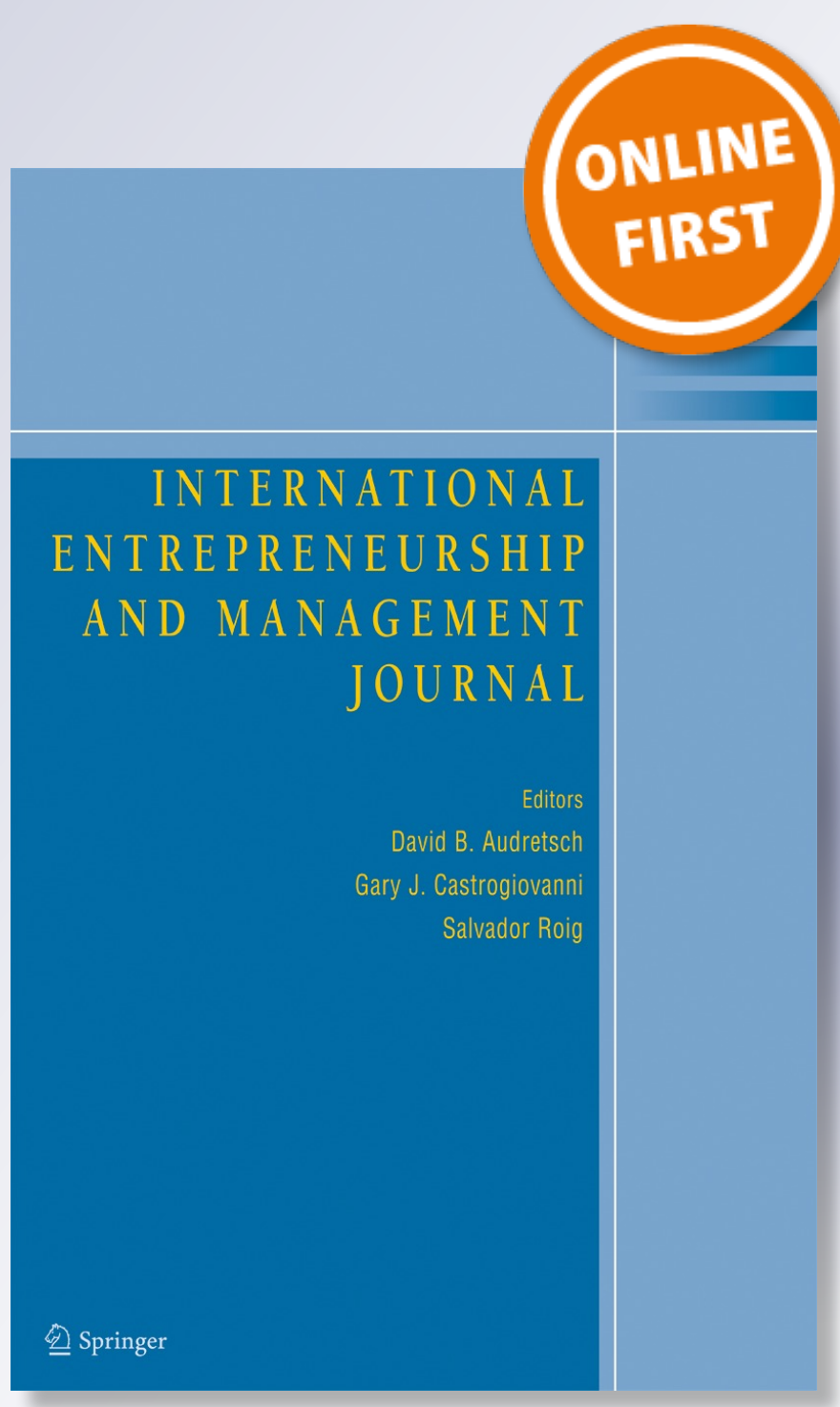

Springer 
Your article is protected by copyright and all rights are held exclusively by Springer Science +Business Media New York. This e-offprint is for personal use only and shall not be selfarchived in electronic repositories. If you wish to self-archive your article, please use the accepted manuscript version for posting on your own website. You may further deposit the accepted manuscript version in any repository, provided it is only made publicly available 12 months after official publication or later and provided acknowledgement is given to the original source of publication and a link is inserted to the published article on Springer's website. The link must be accompanied by the following text: "The final publication is available at link.springer.com". 


\title{
Special issue on "The role of networks in entrepreneurial performance: new answers to old questions?"

\author{
Guest Editors' Introduction
}

\author{
Wilson Ng • Alison Rieple
}

(C) Springer Science+Business Media New York 2014

\begin{abstract}
The nature and extent of relationships between entrepreneurial networks and entrepreneurial performance are old questions. Scholars have explored the nature of entrepreneurial networks and have focused on their relationship with, and effects on, performance, which is viewed in this special issue in terms of the strategic development of established businesses and new ventures. However, while much is now known about the origins and effects of social networks there continues to a paucity of research on how social networks are used in various organizations, and when one or more networks are drawn upon for what specific purpose. Each article in this special issue addresses one or more of these questions in a range of industries and environments, namely poor village entrepreneurs who have to work in a highly challenging financial and social environment in Bangladesh, "early internationalizing small firms" in South Africa, high technology "early-stage ventures" in Hong Kong, 3-D technology ventures that operate with an "open" business model, and the "multi-rational" nature of networks in family businesses in and beyond the UK. In all, this collection of papers comprises a body of scholarship with fine-grained studies on how and when specific social networks are drawn on in various forms of organization. The subsequent discussion of these issues extends knowledge of the various ways in which entrepreneurs and entrepreneurial businesses advance their interests by leveraging familiar business and social networks.
\end{abstract}

Keywords Social networks $\cdot$ Social capital $\cdot$ Network ties $\cdot$ Technology ventures and start-ups $\cdot$ Entrepreneurial performance

The above Guest Editors of this special issue contributed equally to the issue \& their names are listed alphabetically.

\section{W. Ng $(\bowtie)$}

Roehampton University Business School, Roehampton University London, London SW15 5SL, UK e-mail: Wilson.Ng@roehampton.ac.uk

\author{
A. Rieple \\ Westminster Business School, University of Westminster, London NW1 5LS, UK \\ e-mail: rieplea@westminster.ac.uk
}




\section{Introduction}

Why are we interested in the role of networks in entrepreneurial ventures? A considerable body of literature already exists on entrepreneurial networks, and quite a lot is now known about their nature and effects in a range of industries and on a variety of organizations. We know for example that the principal role of many entrepreneurs is in building networks- talking with and building relationships with a range of parties (Greve and Salaff 2003), and that their "social competence" in building suitable social and personal networks of contacts for their businesses can be closely related to their financial success (Baron and Markman 2003). At the planning stage entrepreneurs talk to more people than at later stages of the business as they seek ways to build and establish the business (Greve and Salaff 2003), and "discussion networks" are formed in a systematic way during different stages of entrepreneurship to explore business ideas but also to try and satisfy needs of a particular stage of the process. This is especially important for acquiring and exploiting external knowledge in technology ventures, for example, in new product development (Yli-Renko et al. 2001).

Further, inter-firm networks can produce significant, positive effects on the performance of firms that are able to leverage their networks from their business and social interests to capture valuable market opportunities (Lechner and Dowling 2003). By entrepreneurial performance we mean the financial growth and/or strategic development of entrepreneurial ventures, businesses, and other organizations. In the social network literature strong ties have often been related specifically to the growth in sales of new and old firms (Collins and Clark 2003), while in newer, high technology ventures sales growth founded on distinct internal capabilities- for example, valuable technological knowledge and production skills that competitors find difficult to imitate- have been strong predicators of the performance of these organizations (Lee et al. 2001).

Firm performance may also be influenced by path-dependent relational capability that then leads to a reconfiguration of internal and external networks in the networked firm (Lechner and Dowling 2003; Rothaermel and Hess 2007). The relational capability of firms- their social capital- is typically built on a founding entrepreneur's personal networks, which can consist of strong but also frequently weak social ties (Brüderl and Preisendörfer 1998). In mature firms social capital both inside (with colleagues) and outside the firm (with customers and other external stakeholders) may be built over time from regular interaction between stakeholders at various levels of the organization (Mizruchi and Brewster-Stearns 2001) and not merely at its apex.

Yet this accumulated knowledge about entrepreneurial networks focuses largely on the outcomes and effects of social capital- the "what" questions of entrepreneurial performance. By contrast, there remains a paucity of knowledge about the nature of this performance- how an organization's networks are leveraged and when networks are applied in its specific circumstances, for example in a start-up or early-stage business seeking to establish a foothold in the marketplace (Shane and Cable 2002). This is the reality of performance-as-survival in ventures with few business networks where the processes in which the entrepreneur's personal networks are drawn on can be decisive, for example, when searching for financing in the marketplace (ibid.). Here social ties provide an important mechanism with which a venture's financiers may address gaps in information about the venture. In the absence of high-capital endowments, direct and 
indirect ties between entrepreneurs and investors, and their networks influence the selection and funding of ventures (ibid.).

However, the point at which Shane and Cable (2002) and other research on entrepreneurial networks (e.g. Aarstad et al. 2010; Arregle, et al. 2013; Semrau and Werner 2013; Sullivan and Ford 2013) ends is where our specific interest in the processes of these networks begins. This is because there continues to be a relative paucity of knowledge in this literature of how internal and external networks may be used for what purpose(s) in organizations, and when one or more networks are drawn upon in organizations to address a specific purpose. These gaps seem to exist especially in the contexts of less developed environments (see, for example, the article by Maas, Seferiadis, Bunders, \& Zweekhorst in this special issue).

Furthermore, we have observed that despite considerable theoretical development on the effects of social ties (e.g. Jansen et al. 2013; Fornoni et al. 2011; Fuentes et al. 2010; Scarbrough et al. 2013) there remains little empirical evidence on the processes in which entrepreneurial networks produce outcomes in terms of business growth and the effects of networks on stakeholders of the entrepreneurial organization (Baron and Markman 2003). This paucity of empirical evidence seems to come into sharp focus in entrepreneurial ventures with few resources save for the founder's business and social networks (see, for example, Stuart and Sorenson 2007). Here, in nascent ventures across a range of industries, the founders' personal networks shape their firms' strategic development by influencing their capability for innovation (Romijn and Albaladejo 2002; Stuart and Sorenson 2007), and for identifying and pursuing subsequent entrepreneurial opportunities (Stuart and Sorenson 2007), and by influencing the membership and entrepreneurial direction of management teams (Aldrich and Kim 2007). Similarly, firms with broader networks are known to have access to a wider range of investment opportunities with better financial returns (Sorenson and Stuart 2008).

We were therefore motivated to address these issues in a special edition by our observations of the way in which the literature on entrepreneurial networks had evolved- or more accurately, about the way in which the literature had not evolved to explore the how and when issues of networks and their effects on the enterprise. To address these issues that we collectively call the processes of entrepreneurial networks we have assembled a range of articles that offer fine-grained enquiry into network processes in a range of organizations that originated and are operating in various industries and environments internationally. We strongly believe that theories about entrepreneurial networks need to be grounded in empirical research of their processes- the ways in which organizations leverage and apply an important resource in pursuing and securing entrepreneurial opportunities (Hoang and Antoncic 2003). We believe that all of the papers that appear in this special issue make a significant contribution in addressing this gap on the ways in which these networks operate without focusing merely on the effects or outcomes of strong and weak networks.

At the deadline for submissions on 30 September 2012, 25 articles were received. From this total 20 articles were deemed to address the focus of the special issue on the role of entrepreneurial networks and were sent for review. Ten articles were then invited for resubmission, and following further rounds of reviews five articles were accepted. These five articles are presented in this issue. 
Our final collection of articles represents a range of methodological approaches and theoretical perspectives from organization-based studies of single firms and multiple firms to cross-industry and international field studies; and the articles explore nongovernment organizations and social enterprises, start-ups and early stage ventures, small but rapidly internationalizing firms, and family businesses. Data were analyzed at various levels of analysis, namely at an organizational, inter-organizational, or industry level.

The overall picture that emerges is of rich and fine-grained studies of network processes in which various forms or types of organizations with little market reputation and business networks seek to enhance their prospects by drawing on specific, personal networks of key internal stakeholders- typically founder-entrepreneurs and key partner-managers co-opted into the venture- and by leveraging their chosen networks to gain competitive advantage. The basis for advantage included superior market positioning, knowledgeable management of customers and other key stakeholders, and in the case of social enterprises, prior influence among peer groups in the organization's industry.

We now introduce our collection of articles, beginning with research drawing from data outside the European Union, and suggest a few, distinct insights that each article offers on the role of networks in the processes of business development in entrepreneurial organizations and entities:

\section{Maas, Seferiadis, Bunders, \& Zweekhorst: "Bridging the disconnect: how network creation facilitates female Bangladeshi entrepreneurship"}

In this article the authors explore how female social entrepreneurs develop and use their social ties in Bangladesh, a highly resource constrained environment that is also socially restrictive for women. The article paints an intricate picture of how an "external actor" in the networks of female entrepreneurs, namely PRIDE, a non-government organization, may stimulate the development of business networks in partnership with entrepreneurs.

The heart of the research comprised longitudinal data on the social ties of female Bangladeshi entrepreneurs which were gathered over three and a half years from the Social Entrepreneurial Leadership programme (SEL) of PRIDE, where SEL trains female entrepreneurs to build- where necessary from scratch- their own business networks. The research design involved several methods of data collection, chiefly written reports and interviews from a long-running monitoring programme. This monitoring programme produced monthly reports from PRIDE on the progress and use of the SELs' network development, and the authors discuss a number of these reports with PRIDE staff and separately with female entrepreneurs and associated parties in a range of settings.

In interpreting their findings, the authors adopt a social capital perspective on entrepreneurial networks to gain insights into the mechanisms that help to build networks for ultra-poor entrepreneurs, and into the ways in which those networks influence entrepreneurial outcomes. Based on their findings the article identifies a deeply engaged process in which the external actor PRIDE played an indispensable role in supporting and at times encouraging and prompting ultra-poor, village entrepreneurs in building their entrepreneurial networks. 


\section{Masango \& Marinova: "Knowledge-based network ties in early rapidly internationalising small firms: a missing link?"}

In their article Masango \& Marinova explore the specific characteristics, development patterns and functions of network ties facilitating the internationalisation of "early rapidly internationalising small firms" (ERISFs), an important type of firm in international entrepreneurship studies that is principally engaged in high technology and knowledge intensive businesses. Drawing on multiple case studies of the sources of network ties in ten high technology firms that are engaged in biotechnology, communications and gaming technology in South Africa, the authors suggest that founders' pre-firm knowledge pools play a key role in establishing initial knowledge-based interpersonal ties in ERISFs' cross border activities. The focus on high technology firms in South Africa seems topical given the emergence of a critical mass of these firms in and around several major cities, while the authors reflect on interview data mainly with founders of ERISFs in proposing an initial, prior interpersonal network tie set that is composed of predominantly strong knowledge-based contacts. Network ties of high technology firms are seen to conduct activities that the authors identify and group in three distinct types of activities, as knowledge creation, transfer, or adoption activities. In particular it is suggested that the research findings offer significant evidence of knowledge creation and transfer activities.

\section{Cautela, Pisano, \& Pironti: "The emergence of new business model configurations from technology innovation: an analysis of 3-D printing ventures"}

By contrast with other studies in this special issue Cautela, Pisano, \& Pironti view entrepreneurial networks in terms of a new business model that has emerged and is being used by designer-entrepreneurs as they seek to develop new types of businesses in the design service industry using 3-D printing technology. Four propositions are put forward on the nature of 3-D printing and its use in design ventures that may support the development of an effective, open business model for these ventures.

The paper is based on case studies of the business models of three design firms. In addition to their case studies, the authors interviewed three professors of design technology in various environments (California, UK, and Italy) in seeking to gain a deeper understanding of the nature and possible applications of 3-D printing in design firms located in the respective locations. Three internet blogs on 3-D printing were also analyzed in seeking to learn how the design market views the development and use of this technology and which organizations have featured most often in connection with it.

The result is an intricate picture of the way in which a contemporary phenomenon, 3-D printing, which has already received much publicity in the media for its possible applications in and beyond design fields, has prompted the development of an "open" business model as design ventures seek to tap creativity in the marketplace to develop the nascent technology. 


\section{Ng, Macbeth, \& Southern: "Entrepreneurial performance of early-stage ventures: dynamic resource management for development and growth"}

$\mathrm{Ng}$, Macbeth, \& Southern in their article explore how intellectual capital (IC) may be used as a critical network resource for entrepreneurial performance in early-stage ventures (ESVs). Drawing on case studies of IC strategies in four semiconductor and wireless communications ESVs in Hong Kong, the authors develop a conceptual framework of IC in the development and growth of ESVs and suggest how a dynamic process of allocating IC resources may be optimally coordinated by ESV founders as their venture grows and develops.

The article's framework builds on prior research of IC that has distinguished four IC components with a significant impact on business performance: human capital, innovation capital, structural capital and customer capital. Exploring how financial resources are allocated in each of these IC components in the course of the development of the case firms, the article critically examines how far each component of IC may be leveraged by founders and managers of the four cases as they seek to develop their ESVs and attract new customers. Here a key contribution of the article is to resourcenetwork theory, for example of Weiss and Birnbaum (1998) and Wilson and AppiahKubi (2002), where the article paints a detailed picture of an "evolving process" of developing and using heterogeneous resources as ESV managers seek to constantly reconfigure the combination of IC resources in their firms to try and enhance their development.

The authors suggest that their ESVs' continuing reconfiguration of resources is intended to improve their competitiveness by improving their ability to exploit business opportunities. This process advances previous research on the role of resources in enhancing the growth and development of ESVs by suggesting how each of the four IC components relates with a number of external factors and stakeholders, including the ESV's business networks, alliances, and partnerships. The process that the article describes in the way that the development in the strength of internal resources- the ESV's IC components- improves the venture's capability to acquire external networks also contributes importantly to the theme of this special issue in that we learn how the subsequent strength of relationship between internal resources and external networks constitutes a key element in enhancing business expansion in high technology ESVs. In turn, the industry experience and networking ability of ESV founders and executives provide them with a platform to execute business plans and to attract new customers for products and services that were developed from partnerships between an ESV's external networks and its internal IC components.

\section{Seaman, McQuaid, \& Pearson: "Networks in family business: a multi-rational approach"}

The fifth article presented in this special issue is a conceptual paper that explores and argues in favour of a "multi-rational" approach to studying family business networks, where the family's network of relations, the firm's business connections, and employees' personal networks interact and overlap in a number of family businesses. 
By contrast, it is suggested that current research on networks in family businesses has adopted a "mono-rational" perspective in which the three groups of networks have been considered to be pretty indistinctive or isolated from one other. A framework of multiple rationalities is presented with which family business networking may be viewed and, it is argued, better understood in terms of the interaction of the three different networks in family businesses.

Based on extant literature on networks in family businesses and in small and medium-sized enterprises, the authors propose three key concepts that influence the networking process and which they argue are particularly relevant in family businesses: redundancy (where many of the family firm's contacts know one other and may therefore provide similar information), kinship, and diversity. The article describes each concept and then proceeds to explore the process in which these concepts interact and overlap with one another by drawing on the work of Louis Filion (1990), who explored the three levels of network relations in suggesting how the founderentrepreneur's personal relationships have significant influence on the development of the entrepreneurial firm.

Applying Filion's (1990) research on mid-sized enterprises to small family-owned businesses, the authors suggest that friendship and business networks may play a vital role in the enterprise's success but that each network offers different perspectives, knowledge and rationales for the strategic development of the business. Further, family members in the business are likely to relate with different people at different times in different ways, and for different immediate ends. The authors contend that these different "multi-rationalities" may influence the manner in which networks develop and hence may also influence the network capital available to the business, thereby constraining the family firm's performance and development. Here the article's theoretical contribution is in suggesting that where family business scholars consider that the firm's networks operate from a multi-rational perspective then accrued benefits could include greater understanding of the processes of networking and opportunities to develop targeted business support for small, entrepreneurial-minded family businesses. Further, family business researchers with a multi-rational perspective may go on to explore how this perspective could help to develop thinking on the distinction between family and non-family business research. An implication of this distinction in studying family business networks is in the possible differences that then emerge between the networks of family-based and one-family owned businesses of similar size and/or sector of operations, and this question of possible differences would raise additional research questions, for example, on the effects of each level or type of network on entrepreneurial performance.

In closing our Introduction may we record, in alphabetical order, the contributions of the following colleagues who repeatedly and generously gave of their expertise and time through several stages of the review process. We are very grateful to them.

Dr Jane Chang

Dr Ioannis Christodoulou

Dr Denise Dollimore

Dr Felicity Hardley

Dr Martin Mathews

Mr Stephen O'Regan

Dr Declan Scully 


\section{References}

Aarstad, J., Haugland, S. A., \& Greve, A. (2010). Performance spillover effects in entrepreneurial networks: assessing a dyadic theory of social capital. Entrepreneurship: Theory and Practice, 34(5), 1003-1019.

Aldrich, H., \& Kim, P. (2007). Small worlds, infinite possibilities? How social networks affect entrepreneurial team formation and search. Strategic Entrepreneurship Journal, 1(1-2), 147-165.

Arregle, J. L., Batjargal, B., Hitt, M. A., Webb, J. W., Miller, T., \& Tsui, A. S. (2013). Family ties in entrepreneurs' social networks and new venture growth. Entrepreneurship: Theory and Practice. doi:10. 1111/etap.12044/pdf.

Baron, R., \& Markman, G. (2003). Beyond social capital: the role of entrepreneurs' social competence in their financial success. Journal of Business Venturing, 18(1), 41-60.

Brüderl, J., \& Preisendörfer, P. (1998). Network support and the success of newly founded businesses. Small Business Economics, 10(3), 213-225.

Collins, C., \& Clark, K. (2003). Strategic human resource practices, top management team social networks, and firm performance: the role of human resource practices in creating organizational competitive advantage. Academy of Management Journal, 46(6), 740-751.

Filion, L. (1990). Entrepreneurial performance, networking, vision and relations. Journal of Small Business and Entrepreneurship, 7(3), 3-13.

Fornoni, M., Arribas, I., \& Vila, J. E. (2011). Measurement of an individual entrepreneur's social capital: a multidimensional model. International Entrepreneurship and Management Journal, 7(4), 495-507.

Fuentes, M. D. M. F., Arroyo, M. R., Bojica, A. M., \& Pérez, V. F. (2010). Prior knowledge and social networks in the exploitation of entrepreneurial opportunities. International Entrepreneurship and Management Journal, 6(4), 481-501.

Greve, A., \& Salaff, J. (2003). Social networks and entrepreneurship. Entrepreneurship: Theory and Practice, $28(1), 1-22$.

Hoang, H., \& Antoncic, B. (2003). Network-based research in entrepreneurship: a critical review. Journal of Business Venturing, 18(2), 165-187.

Jansen, R. J., Curşeu, P. L., Vermeulen, P. A., Geurts, J. L., \& Gibcus, P. (2013). Information processing and strategic decision-making in small and medium-sized enterprises: the role of human and social capital in attaining decision effectiveness. International Small Business Journal, 31(2), 192-216.

Lechner, C., \& Dowling, M. (2003). Firm networks: external relationships as sources for the growth and competitiveness of entrepreneurial firms. Entrepreneurship \& Regional Development: An International Journal, 15(1), 1-26.

Lee, C.-W., Lee, K.-M., \& Pennings, J. (2001). Internal capabilities, external networks, and performance: a study on technology-based ventures. Strategic Management Journal, Special issue on "Strategic entrepreneurship: Entrepreneurial strategies for wealth creation", 22(6-7), 364-381.

Mizruchi, M., \& Brewster-Stearns, L. (2001). Getting deals done: the use of social networks in bank decisionmaking. American Sociological Review, 66(5), 647-671.

Romijn, H., \& Albaladejo, M. (2002). Determinants of innovation capability in small electronics and software firms in southeast England. Research Policy, 31(7), 1053-1067.

Rothaermel, F., \& Hess, A. (2007). Building dynamic capabilities: innovation driven by individual-, firm-, and network-level effects. Organization Science, 18(6), 898-921.

Scarbrough, H., Swan, J., Amaeshi, K., \& Briggs, T. (2013). Exploring the role of trust in the deal-making process for early-stage technology ventures. Entrepreneurship: Theory and Practice, 37(5), 12031228.

Semrau, T., \& Werner, A. (2013). How exactly do network relationships pay off? The effects of network size and relationship quality on access to start-up resources. Entrepreneurship: Theory and Practice. doi:10. 1111/etap.12011/pdf.

Shane, S., \& Cable, D. (2002). Network ties, reputation, and the financing of new ventures. Management Science, 48(3), 364-381.

Sorenson, O., \& Stuart, T. (2008). Bringing the context back in: settings and the search for syndicate partners in venture capital investment networks. Administrative Science Quarterly, 53(2), 266-294.

Stuart, T., \& Sorenson, O. (2007). Strategic networks and entrepreneurial ventures. Strategic Entrepreneurship Journal, 1(3-4), 211-227.

Sullivan, D. M., \& Ford, C. M. (2013). How entrepreneurs use networks to address changing resource requirements during early venture development. Entrepreneurship: Theory and Practice. doi:10.1111/ etap.12009/pdf. 
Weiss, A., \& Birnbaum, P. (1998). Technological infrastructure and the implementation of technological strategies. Management Science, 35(8), 1014-1027.

Wilson, H., \& Appiah-Kubi, K. (2002). Resource leveraging via networks by hi-technology entrepreneurial firms. Journal of High Technology Management Research, 13(1), 45-62.

Yli-Renko, H., Autio, E., \& Sapienza, H. (2001). Social capital, knowledge acquisition, and knowledge exploitation in young technology-based firms. Strategic Management Journal, 22(6-7), 587-613. 